\title{
The Influence of Electronic Perturbations on the Sulfur-Fluorine Gauche Effect
}

M. Sc. Christian Thiehoff ${ }^{[a]}$, Lukas Schifferer ${ }^{[a]}$, Dr. Constantin G. Daniliuc ${ }^{[a, \S]}$, Dr. Nico Santschi ${ }^{[a, b]} *$, Prof. Dr. Ryan Gilmour ${ }^{[a, b] *}$

[a] Institute for Organic Chemistry, Westfälische Wilhelms-Universität Münster, Corrensstrasse 40, Münster, Germany. E-Mail: santschi@uni-muenster.de,ryan.gilmour@uni-muenster.de

[b] Excellence Cluster EXC 1003, Cells in Motion, Westfälische Wilhelms-Universität, Münster, Germany.

${ }^{[\S]}$ X-ray crystallographer.

Dedicated to Prof. Dr. Antonio Togni on the occasion of his $60^{\text {th }}$ birthday.

\section{Keywords}

Conformation analysis, Hyperconjugation, NMR spectroscopy, Physical organic chemistry, SulfurFluorine Gauche Effect

(C) 2016. This manuscript version is made available under the Elsevier user license http://www.elsevier.com/open-access/userlicense/1.0/ 


\section{Abstract}

Herein, a solution phase NMR conformer population analysis is employed to probe the effect of remote electronic perturbations on the conformational equilibria of a series of para-substituted $\beta$ fluorosulfides (1), sulfoxides (2) and sulfone derivatives (3). Conformations that allow for stabilizing stereoelectronic $\left(\sigma_{\mathrm{C}-\mathrm{H}} \rightarrow \sigma^{*}{ }_{\mathrm{C}-\mathrm{F}}\right)$ and electrostatic $\left(\mathrm{F}^{\delta-} \ldots \mathrm{S}^{\delta+}\right)$ interactions predominate: this is consistent with the Sulfur-Fluorine Gauche Effect. The molar fractions $(\mathrm{X})$ of the two possible gauche conformers correlate linearly with the electron-withdrawing aptitude of the para-substituent, rendering the system ideally suited for a Hammett-type analysis. Despite the clear influence that the remote parasubstituents have on conformer population, this is superseded by the oxidation state on sulfur (II, IV, $\mathrm{VI})$, where an increased preference for the gauche conformer follows the trend: sulfide $<$ sulfone $<$ sulfoxide. It is envisaged that this proof of concept in controlling conformer population, either by proximal (oxidation state) or remote tuning (para-substituent), will find application in molecular design.

\section{Introduction}

The fluorine-heteroatom gauche effect describes the preference of a generic 1,2-disubstituted $\beta$ fluoro-ethane fragment (F-C1-C2-X) to preferentially adopt gauche conformations over the anti arrangement (Figure 1). ${ }^{[1]}$ This intriguing behaviour is a consequence of fluorine's high electronegativity and negligible steric footprint: Together these features allow this counterintuitive syn-clinal arrangement to predominate by simultaneously facilitating stabilising hyperconjugative interactions, to engage the low-lying anti-bonding orbital of the C-F bond (e.g. $\sigma_{\mathrm{C}-\mathrm{H}} \rightarrow \sigma^{*}{ }_{\mathrm{C}-\mathrm{F}}$ ), without generating un-favourable non-bonding interactions. Indeed this latter feature allows proximal groups with opposing (partial) charges to interact electrostatically, further augmenting the interaction. As a general rule, the electron-withdrawing capability of the heteroatom substituent $(X)$, can be correlated with the gauche conformational bias. Whilst this notion is well studied and has found 
widespread application with second period elements $(\mathrm{N}, \mathrm{O}, \mathrm{F}){ }^{[2]}$ it was only recently extended to a third period element by this laboratory; a phenomenon termed the Sulfur-Fluorine Gauche Effect. ${ }^{[3]}$ This extension to sulfur-based systems seemed highly prudent on account of the multiple oxidations states associated with sulfur (II, IV, VI). It was envisaged that sequential oxidation could be exploited as a mechanism by which the conformational equilibrium of the $\mathrm{F}-\mathrm{C} 1-\mathrm{C} 2-\mathrm{S}(\mathrm{O})_{\mathrm{n}}$ fragment could be regulated.

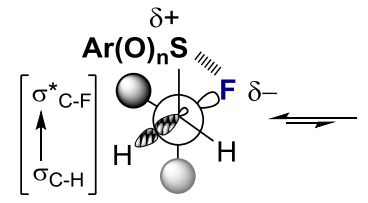

gauche $^{1}$

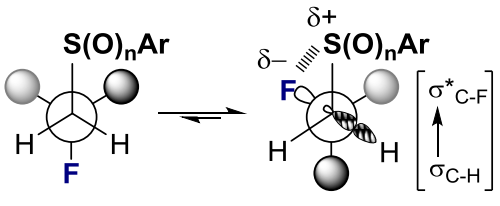

anti gauche ${ }^{2}$

Figure 1. Conformational equilibria in $\mathrm{F}-\mathrm{C} 1-\mathrm{C} 2-\mathrm{S}(\mathrm{O})_{n} \mathrm{R}$ systems: the Sulfur-Fluorine Gauche Effect. ${ }^{[3]}$

Recently, a computational study by Baranac-Stojanović and co-workers delineated the origins of this unprecedented conformational preference and concluded that primarily electrostatic interactions are responsible for this phenomenon. ${ }^{[4]}$ Whilst in sulfur analogues of cyclic proline-derived systems the population of the gauche conformer increases noticeably following the trend sulfide $<$ sulfone $<$ sulfoxide, the effect of more subtle, remote electronic modulation has yet to be established and was the motivation for this investigation. By introducing para-substituted aryl sulfide, sulfoxide or sulfone units into the model systems (i.e. F-C1-C2-S(O) $\mathrm{Ar}$ ), it was envisaged that the conformational population, as a function of sulfur oxidation state, could be further tuned by a remote handle. From the perspective of molecular design, this is an attractive strategy on account of the increased frequency with which fluorine stereoelectronic effects are finding application in catalysis and biomedical sciences. ${ }^{[1 b-d, 5]}$ 


\section{Results and Discussion}

To provide a fully experimental validation of this working hypothesis, and complement the existing theoretical treatment, ${ }^{[3,4]}$ three sets of electronically modulated compound classes were prepared and subjected to a solution phase conformer population analysis (Figure 2A). Specifically, the electronics of the parent sulfide, sulfoxide and sulfone scaffolds $(\mathbf{1} \mathbf{e}, \mathbf{2 e}, \mathbf{3 e})$ were perturbed through the introduction of electron-donating and electron-withdrawing substituents $\left[\mathrm{R}=\mathrm{NH}_{2}(\mathbf{a}), \mathrm{OH}(\mathbf{b})\right.$, $\mathrm{OMe}(\mathbf{c}), \mathrm{Me}(\mathbf{d}), \mathrm{H}(\mathbf{e}), \mathrm{F}(\mathbf{f}), \mathrm{Cl}(\mathbf{g}), \mathrm{CO}_{2} \mathrm{H}(\mathbf{h}), \mathrm{CO}_{2} \mathrm{Et}(\mathbf{i})$ and $\left.\mathrm{NO}_{2}(\mathbf{j})\right]$. Furthermore, the corresponding thioester 4 was explored on account of the importance of acetyl-CoA in biosynthetic transformations, ${ }^{[6]}$ and finally the thiocyanate 5 bearing an electron deficient S-atom. These systems serve as valuable scaffolds to comparatively evaluate how subtle electronic attenuations translate into conformer populations, as reflected by the respective molar fractions ( $\chi_{1}, \chi_{11}, \chi_{111} ;$ Figure $\left.2 \mathrm{~B}\right)$.

A

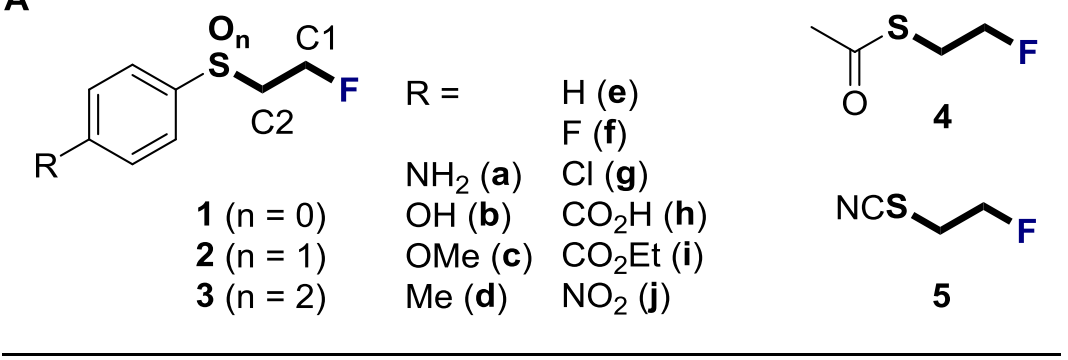

B

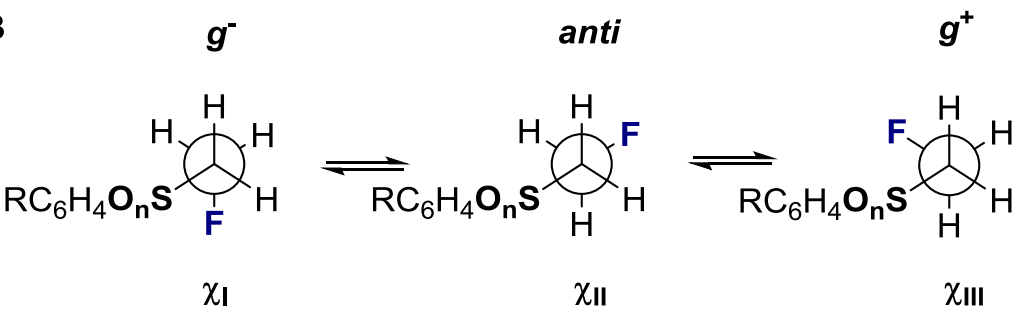

Figure 2. A: The sulfides (1a-j), sulfoxides (2a-g, $\mathbf{i}-\mathbf{j})$ and sulfones $(\mathbf{3 a -} \mathbf{g}, \mathbf{i}-\mathbf{j})$ as well as thioester $\mathbf{4}$ and thiocyanate $\mathbf{5}$ used in this study. B: The three staggered conformers partitioned by $120^{\circ}$ that were considered and described as molar fractions $\left(\chi_{1}, \chi_{\| 1}, \chi_{111}\right)$. 
Preparation of the target sulfides (1a-j) proved facile and could be achieved by unifying commercially available, para-substituted thiophenols with 2-fluoroethane tosylate. The desired products were generated cleanly and in good yields (24-87\%) (Figure 2A). Through sequential oxidation using $m$ CPBA it was possible to access the respective sulfoxides (2a-g,i-j; $40-89 \%)$ and ultimately the sulfones (3a-g,i-j; $40-89 \%$ ) (Full experimental details are provided in the supporting information). Since compound $\mathbf{1 h}$ was the synthetic precursor for $\mathbf{1 i}$ it was also included in the ensuing analysis, however, the corresponding sulfoxide and sulfone to $\mathbf{1 h}$ were not prepared. S-(2-fluoroethyl) thioacetate (4) and 1-fluoro-2-thiocyanatoethane (5) were prepared in 44 and $38 \%$ yield by treating 2-fluoroethane tosylate with sodium thioacetate and sodium thiocyanate, respectively, following a literature protocol. ${ }^{[7]}$

Despite the structural diversity of the systems 1 - $\mathbf{3}$ prepared, very few samples proved to be crystalline thereby precluding the use of crystallographic techniques for the conformational analysis.

The solution phase NMR analysis was performed with the pre-condition that only the three conformers partitioned by $120^{\circ}$ would be considered: these include the two gauche $\left(g^{+} / \mathrm{g}^{-}\right)$ arrangements and the corresponding anti conformation (Figure 2B). Furthermore, in the case of the sulfide ( $n=0)$ and sulfone $(n=2)$, substitutions $g^{+}$and $g^{-}$are equivalent and thus the sum of both is reported. The required NMR samples were prepared in $\mathrm{CDCl}_{3}$ at concentrations between 0.1 and 0.2 $\mathrm{mM}$ and standard experiments $\left({ }^{1} \mathrm{H} \&{ }^{19} \mathrm{~F}\right)$ were conducted at ambient temperature.

The following population analysis was based on the experimental $\left\langle^{3} J_{\mathrm{HF}}\right\rangle$ coupling constants as summarized in Table 1 and theoretical values $\left(J^{\text {anti }}\right.$ and $\left.J^{\text {gauche }}\right)$, which were determined as previously described by Béguin and co-workers. ${ }^{[8]}$ Hence, $J^{\text {anti }}$ and $J^{\text {gauche }}$ were calculated according to $J^{\text {anti }}=65.75$ $-7.52 \times \Sigma(\Delta E)$ and $\jmath^{\text {gauche }}=15.35 \times \exp (-0.266 \times \Sigma(\Delta E))$ here $\Sigma(\Delta E)$ represents the sum of the Huggins electronegativity differences between a substituent $\left(\mathrm{SO}_{n} \mathrm{R}, \mathrm{F}\right)$ and hydrogen.

For fluorine, a value of 1.70 for $\Delta E$ was used and the sulfur component's group electronegativities relative to hydrogen $(\Delta E)$ are based on the internal proton shift differences $\delta\left(\mathrm{CH}_{3}\right)-\delta\left(\mathrm{CH}_{2}\right)$ of the 
corresponding ethyl derivatives, e.g. EtSPh for $\mathrm{R}=\mathrm{H}$ and $\mathrm{n}=0$ (1e), correlated to group electronegativities previously reported (values tabulated in the supporting information). ${ }^{[8]}$ Thus, $\Delta E$ values were deduced averaging $0.70,0.72$ and 0.89 for sulfide, sulfoxide and sulfone systems, respectively; this is in agreement with group electronegativity values reported for SH (0.76) and $\mathrm{SO}_{2} \mathrm{Cl}(0.69) \cdot{ }^{[9]}$ It is interesting to note that the para-substituent $\mathrm{R}$ only had a small effect on $J^{\text {anti }}$ and $\mathrm{J}^{\text {gauche }}$; this is exemplified by the values of 47.9 and $8.2 \mathrm{~Hz}$, and 47.4 and $8.0 \mathrm{~Hz}$, for the two electronic extremes of the sulfides studied $(n=0)$, i.e. $\mathbf{1} \mathbf{a}\left(\mathrm{R}=\mathrm{NH}_{2}, \sigma_{\text {para }}=-0.66\right)$ and $\mathbf{1 j}\left(\mathrm{R}=\mathrm{NO}_{2}, \sigma_{\text {para }}=0.78\right)$, respectively. As a consequence, when populations were calculated using the $J^{\text {anti }}$ and $J^{\text {gauche }}$ values of the $\mathrm{R}=\mathrm{H}$ derivatives $(\mathbf{1} \mathbf{e}, \mathbf{2 e}, \mathbf{3 e})$ the values obtained typically differed by less than $2 \%$ from those reported in Table 1.

Upon oxidation to the sulfoxide $(\mathrm{n}=1 ; \mathbf{2} \mathbf{a}-\mathbf{g}, \mathbf{i}-\mathbf{j})$ no significant change was observed in $J^{\text {anti }}$ and $J^{\text {gauche }}$ with average values of $47.5 \pm 0.2$ and $8.1 \pm 0.1 \mathrm{~Hz}$ having been calculated. Only in the case of sulfones ( $n=2$; 3a-g,i-j), were smaller values generally observed with average values of $46.2 \pm 0.5$ and $7.7 \pm$ $0.1 \mathrm{~Hz}$ for $J^{\text {anti }}$ and $J^{\text {gauche }}$, respectively. Conversely, the experimental values $\left\langle{ }^{3} J_{\mathrm{HF}}>\right.$ displayed a slightly broader distribution as determined by comparison of the data sets of the electronic extremes $(R=$ $\mathrm{NH}_{2} ; \mathrm{R}=\mathrm{NO}_{2}$ ) with (1a 17.0; $\mathbf{1} \mathbf{j}$ 19.2), (2a [28.0, 21.8]; $\left.\mathbf{2 j}[30.3,20.5]\right)$ and (3a 21.4; $\left.\mathbf{3} \mathbf{j} 22.7\right) \mathrm{Hz}$ for $\mathrm{n}=$ 0, 1 and 2, respectively. Note that in the sulfoxide system the protons at carbon atom C2 are diastereotopic, thus resulting in two experimentally distinct coupling constants $<^{3} J_{\mathrm{HF}}>$. To translate these values into gauche conformer populations $\chi_{1}$ and $\chi_{\text {III }}$ the data was subjected to analysis using equation (1). The corresponding anti conformer population could be determined by simple extrapolation: $\chi_{\| 1}=1-\chi_{1}-\chi_{\| 11}$.

$\chi_{1 / I I I}=\left(<^{3} J_{H F}>-J^{\text {gauche }}\right) /\left(J^{\text {anti }}-J^{\text {gauche }}\right)$ 
The resulting values determined throughout the course of the study are summarized in Table 1. Additionally, to improve the comparison across the sulfur oxidation states, summed gauche conformer populations were considered $\left(\Sigma g=\chi_{1}+\chi_{I I I}\right)$, which allowed graphical representations of the form $\Sigma g \sim \sigma_{\text {para }}$ to be constructed (Figure 3). For the sulfoxide systems $(n=1)$, the conformer populations were also calculated independently based on the sets of experimental $\left\langle^{3} J_{H H}\right\rangle$ coupling constants of each of the diastereotopic protons adjacent to sulfur: The values obtained correlate well with the initial data set derived from $<^{3} J_{H F}>$ (see supporting information). ${ }^{[8]}$

Table 1. Summary of experimental and calculated coupling constants, the conformer populations ( $\chi_{1}$ $-\chi_{\text {IIII }}$ derived, and the summed gauche populations $(\Sigma g)$.

\begin{tabular}{|c|c|c|c|c|c|c|c|c|c|}
\hline Entry & $\sigma_{\text {para }}^{[a]}$ & $\begin{array}{l}\left\langle{ }^{3} J_{\mathrm{HF}}^{1}\right\rangle / \\
\mathrm{Hz}^{[b]}\end{array}$ & $\begin{array}{l}\left\langle\mathrm{J}_{\mathrm{HF}}^{2}\right\rangle / / \\
\mathrm{Hz}^{[b]}\end{array}$ & $\begin{array}{l}J^{\text {anti }} / \\
\mathrm{Hz}^{[\mathrm{cc}]}\end{array}$ & $\begin{array}{l}J^{\text {gauche }} / \\
\mathrm{Hz}^{[\mathrm{cc}}\end{array}$ & $\chi_{1}\left(g^{-}\right)$ & $\chi_{11}$ (anti) & $\chi_{\text {III }}\left(g^{+}\right)$ & $\Sigma g$ \\
\hline $1 a$ & -0.66 & 17.0 & - & 47.9 & 8.2 & 0.22 & 0.56 & 0.22 & 0.44 \\
\hline $1 b$ & -0.37 & 17.3 & - & 47.8 & 8.1 & 0.23 & 0.54 & 0.23 & 0.46 \\
\hline $1 c$ & -0.27 & 17.2 & - & 47.8 & 8.1 & 0.23 & 0.54 & 0.23 & 0.46 \\
\hline $1 d$ & -0.17 & 17.0 & - & 47.6 & 8.1 & 0.23 & 0.55 & 0.23 & 0.45 \\
\hline $1 e$ & 0 & 17.0 & - & 47.5 & 8.1 & 0.23 & 0.55 & 0.23 & 0.45 \\
\hline $1 f$ & 0.03 & 17.8 & - & 47.7 & 8.1 & 0.24 & 0.51 & 0.24 & 0.49 \\
\hline $1 \mathrm{~g}$ & 0.23 & 17.8 & - & 47.7 & 8.1 & 0.25 & 0.51 & 0.25 & 0.49 \\
\hline $1 \mathrm{~h}$ & 0.45 & 18.0 & - & 47.4 & 8.0 & 0.25 & 0.49 & 0.25 & 0.51 \\
\hline $1 \mathrm{i}$ & 0.45 & 17.8 & - & 47.4 & 8.0 & 0.25 & 0.49 & 0.25 & 0.51 \\
\hline $1 \mathrm{j}$ & 0.78 & 19.2 & - & 47.4 & 8.0 & 0.28 & 0.43 & 0.28 & 0.57 \\
\hline
\end{tabular}




\begin{tabular}{|c|c|c|c|c|c|c|c|c|c|}
\hline $2 a$ & -0.66 & 28.0 & 21.8 & 47.5 & 8.1 & 0.51 & 0.17 & 0.32 & 0.83 \\
\hline $2 b$ & -0.37 & 29.6 & 20.2 & 47.1 & 8.1 & 0.55 & 0.13 & 0.31 & 0.87 \\
\hline $2 c$ & -0.27 & 28.7 & 21.3 & 47.5 & 7.1 & 0.52 & 0.14 & 0.34 & 0.86 \\
\hline $2 d$ & -0.17 & 29.8 & 19.4 & 47.6 & 8.1 & 0.55 & 0.16 & 0.29 & 0.84 \\
\hline $2 e$ & 0 & 30.1 & 19.5 & 47.7 & 8.1 & 0.56 & 0.16 & 0.29 & 0.84 \\
\hline $2 f$ & 0.03 & 30.0 & 19.9 & 47.6 & 8.1 & 0.55 & 0.15 & 0.30 & 0.85 \\
\hline $2 g$ & 0.23 & 30.2 & 19.7 & 47.6 & 8.1 & 0.56 & 0.15 & 0.29 & 0.85 \\
\hline $2 i$ & 0.45 & 30.3 & 19.3 & 47.6 & 8.1 & 0.56 & 0.15 & 0.28 & 0.85 \\
\hline $2 j$ & 0.78 & 30.3 & 20.5 & 47.3 & 8.0 & 0.57 & 0.12 & 0.32 & 0.88 \\
\hline $3 a$ & -0.66 & 21.4 & - & 46.3 & 7.7 & 0.36 & 0.29 & 0.36 & 0.71 \\
\hline $3 b$ & -0.37 & 22.0 & - & 46.3 & 7.7 & 0.37 & 0.26 & 0.37 & 0.74 \\
\hline $3 c$ & -0.27 & 21.8 & - & 46.5 & 7.8 & 0.36 & 0.28 & 0.36 & 0.72 \\
\hline $3 d$ & -0.17 & 21.8 & -- & 46.4 & 7.8 & 0.36 & 0.27 & 0.36 & 0.73 \\
\hline $3 e$ & 0 & 22.0 & - & 46.7 & 7.8 & 0.37 & 0.27 & 0.37 & 0.73 \\
\hline $3 f$ & 0.03 & 22.7 & - & 46.3 & 7.7 & 0.39 & 0.22 & 0.39 & 0.78 \\
\hline $3 g$ & 0.23 & 22.8 & - & 46.4 & 7.7 & 0.39 & 0.22 & 0.39 & 0.78 \\
\hline $3 \mathbf{i}$ & 0.45 & 22.7 & - & 46.2 & 7.7 & 0.39 & 0.22 & 0.39 & 0.78 \\
\hline 3j & 0.78 & 23.8 & - & 44.9 & 7.4 & 0.44 & 0.12 & 0.44 & 0.88 \\
\hline
\end{tabular}

[a] Preferred values taken from reference [10]; [b] determined by ${ }^{1} \mathrm{H}$ NMR spectroscopy; [c] calculated according to reference [8]. 

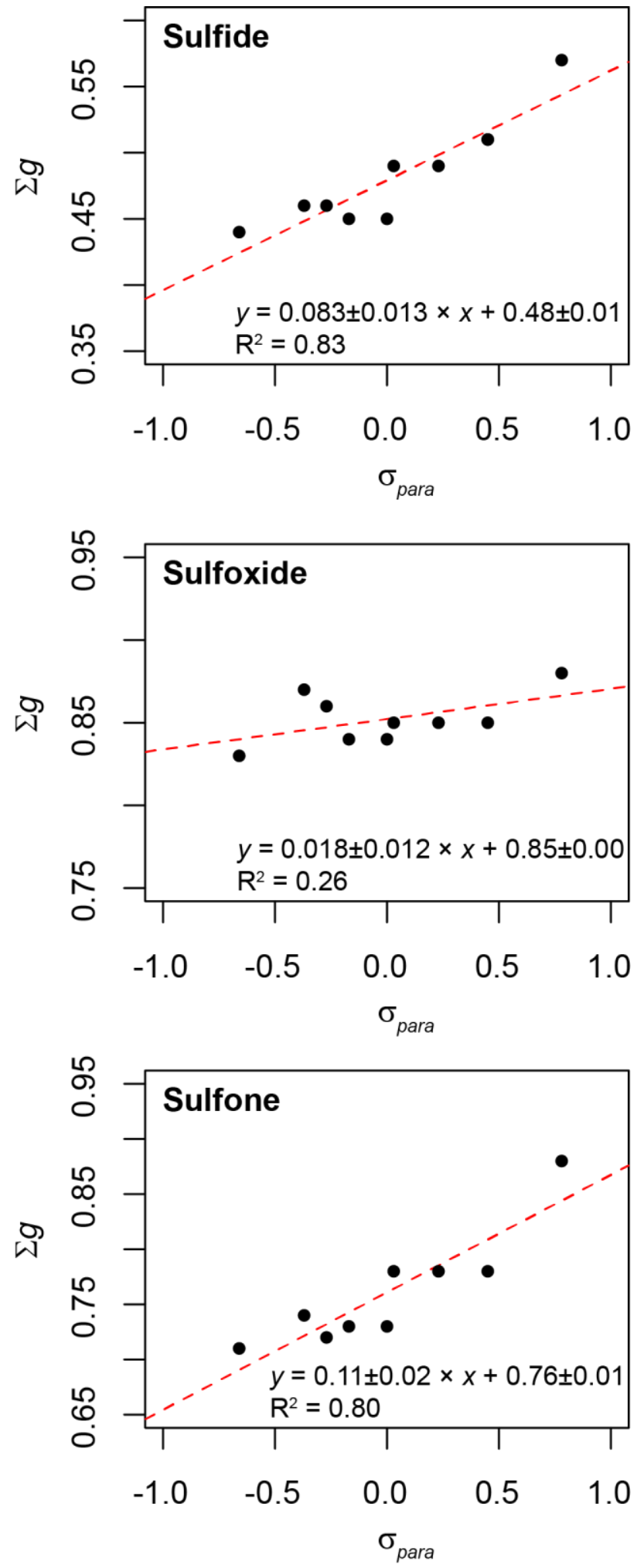

Figure 3. Hammett-type correlations between $\Sigma g$ and $\sigma_{\text {para }}$ for sulfides $\mathbf{1}$, sulfoxides $\mathbf{2}$ and sulfones $\mathbf{3}$. These data suggest that gauche conformation population increases the more electron-withdrawing the substituent $\mathrm{R}\left(\sigma_{\text {para }}>0\right)$. 
Inspection of entries 1a-j in Table 1 indicates that the para-substituent $\mathrm{R}$ has a clear effect on the calculated populations which range from $\Sigma g: a n t i=0.44: 0.56$ to $0.57: 0.43$. This is further supported by the Hammett-type analysis presented in Figure 3, suggesting a linear correlation between the electron-donating $\left(\sigma_{\text {para }}<0\right)$ or electron-withdrawing $\left(\sigma_{\text {para }}>0\right)$ properties of the para-substituent $\mathrm{R}$ and the population of the gauche conformers $\Sigma g$. This logically supports intuition, that the more electron deficient the sulfur centre, the more pronounced the preference for the gauche conformers. This is in line with a stereoelectronic interpretation of the sulfur-fluorine gauche effect, that the key hyperconjugative interaction ( $\sigma_{\mathrm{C2}-\mathrm{s}} \rightarrow \sigma_{\mathrm{C} 1-\mathrm{F}}$ ) should diminish with increasing electron-deficiency of the C2-S bond. However, it should also be noted that since an average value $\Sigma g$ of $0.48 \pm 0.04$ is found, these data suggest that rotation around $\mathrm{Cl}_{1}-\mathrm{CZ}_{2}$ is relatively unhindere in the sulfide system the presence of a small energetic preference for the anti conformer (since for a statistical mixture a $\Sigma g$ value of 0.67 is expected); this is in keeping with our previous results for (2fluoroethyl)(methyl)sulfide (anti preference) and the most recent calculations by Baranac- Stojanović and co-workers for the same sulfide (anti preference). ${ }^{[4]}$

A

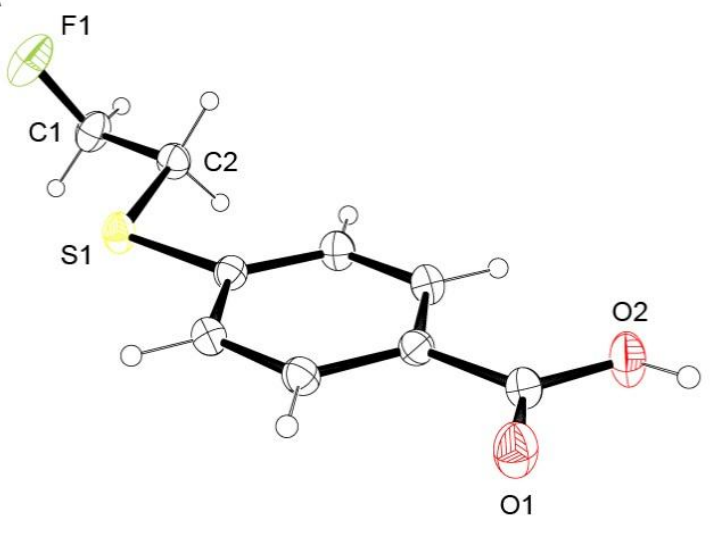

B

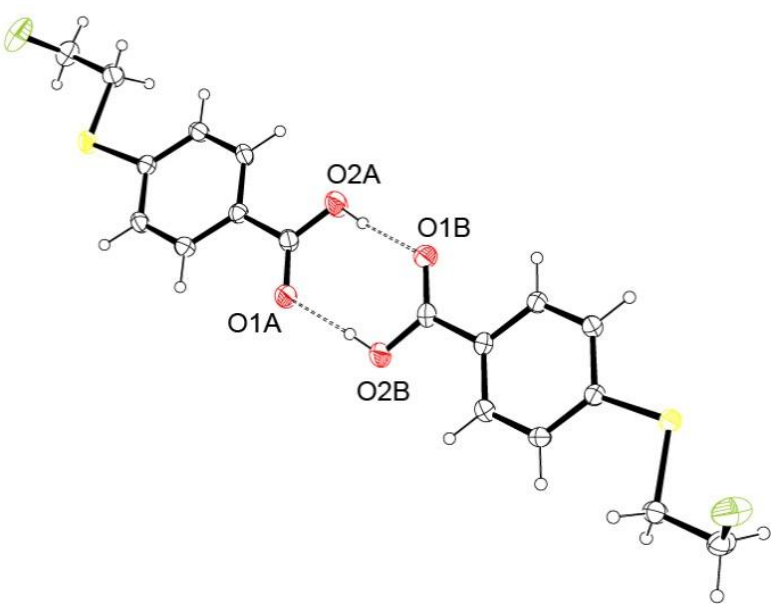

Figure 4. A: X-ray structure of sulfide 1 h. Only one molecule of two found in the asymmetric unit is shown. Thermal elipsoides shown at the $30 \%$ probability level. B: Dimeric structure of $\mathbf{1 h}$ between the two molecules found in the asymmetric unit involving $\mathrm{O}-\mathrm{H} \cdots \mathrm{H}$ interactions. ${ }^{[11]}$ 
In the case of compound $1 \mathrm{~h}\left(\mathrm{R}=\mathrm{CO}_{2} \mathrm{H}\right)$ single crystals that were suitable for solid-state structure determination were obtained by evaporation of a solution in dichloromethane ${ }^{[11]}$ From the analysis, a clear gauche arrangement was found between the fluorine and sulfur atom (F-C1-C2-SAr, torsion angle $\phi_{\mathrm{SCCF}} \approx 67^{\circ}$, Figure 4 ) with geometries that allow for hyperconjugative interactions ( $\phi_{\mathrm{HCCF}} \approx-172^{\circ}$ and $\left.\phi_{\text {HсCS }} \approx-172^{\circ}\right)$. To the best of our knowledge, this constitutes the first X-ray analysis of this fragment sub-class displaying a "sulfide"-fluorine gauche effect. However, the results of the X-ray analysis are in contrast to the initial solution phase analysis, where no profound preference of either Eonformer was found where a small preference for the anti conformer was found ( $\Sigma g$ :anti 0.51:0.49). Furthermore, in the fluoro-ethane motif, bond angles of $110.0^{\circ}$ and $109.8^{\circ}$ were determined for FC1-C2 and $\mathrm{C} 1-\mathrm{C} 2-\mathrm{H}$, respectively. Since these values were available, an angle-dependent determination of $J^{\text {anti }}$ and $J^{\text {gauche }}$ was possible. ${ }^{[12]}$ These values were calculated to be $45.7 \mathrm{~Hz}$ and 12.0 $\mathrm{Hz}$, respectively, thus leading to a marginally altered population ratio of $\Sigma g$ :anti $=0.36: 0.64$, as determined by equation 1 . This discrepancy between solid and solution phase preference may stem from crystal packing effects: the formation of homo-dimers involving the carboxylic acid moiety

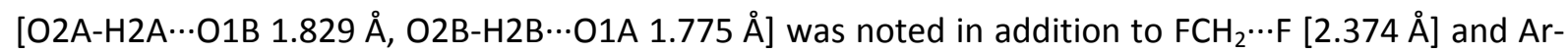

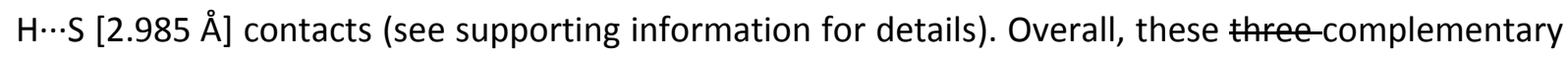
analyses are consistent and reveal the small preference of enerther the anti conformer in the sulfide system (average $\Sigma g$ of $0.48 \pm 0.04$ ): This experimental finding is fully consistent with the theoretical treatment previously reported. ${ }^{[3,4]}$

Upon oxidation to the sulfoxide $(n=1)$, a markedly flatter slope was calculated for the correlation $\Sigma g$ $\sim \sigma_{\text {para }}(0.08 \pm 0.01$ with $n=0 ; 0.02 \pm 0.02$ with $n=1)$ and a low $R^{2}$ value was obtained (Figure 3). In addition, the data display a narrower distribution in comparison to the sulfide system with a difference of $13 \%$ and $5 \%$ for $n=0$ and 1 , respectively, between the minimal and maximal $\Sigma g$ values. Furthermore, the average $\Sigma g$ increased to $0.85 \pm 0.02$. Clearly, the introduction of a second strong dipole moment $(\mathrm{S}=0)$ has an overriding effect. 
Since the molecular structure of sulfoxide $\mathbf{2} \mathbf{j}\left(\mathrm{R}=\mathrm{NO}_{2}\right)$ has previously been reported by this laboratory (CCDC 1048077$)^{[3]}$ and displays a F-C-C-S dihedral angle of $-55.87^{\circ}$, coupling constants $J^{\text {anti }}$ $=41.8 \mathrm{~Hz}$ and $J^{\text {gauche }}=11.0 \mathrm{~Hz}$ could be derived for the angles $\mathrm{F}-\mathrm{C} 1-\mathrm{C} 2$ and $\mathrm{C} 1-\mathrm{C} 2-\mathrm{H}$ of $113.0^{\circ}$ and $108.8^{\circ}$, respectively. Assuming that the major diastereomer crystallized from solution, this conformation should lead to minimization of the overall molecular dipole. At the same time, stabilizing Coulombic interactions (dashed) reinforce the fluorine-sulfur gauche effect (Figure 5). The importance of this electrostatic interaction is further emphasised by the preference of the major diastereomer over the minor with average $\chi_{I}\left(g^{-}\right)=0.55 \pm 0.02$ and $\chi_{I I I}\left(g^{+}\right)=0.30 \pm 0.02$ population values (Table 1). This trend derived from a study of the linear scaffold corresponds well with a previous conformational analysis carried out on a cyclic system. ${ }^{[3]}$

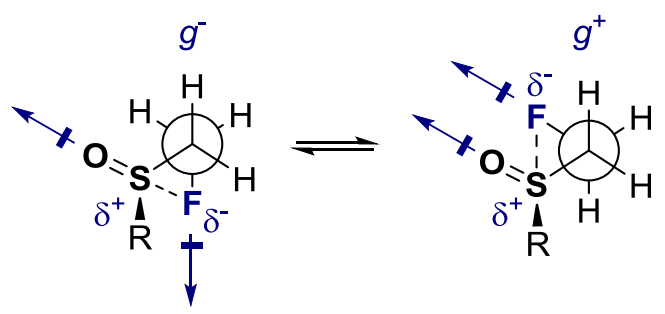

Figure 5. Putative intramolecular interactions (dipole minimization: arrow; Coulomb interaction: dashed) in the $g^{+}$(minor) and $g^{-}$(major) sulfoxide conformers $(n=1)$.

Finally, oxidation to the sulfone $(n=2)$, which removes the stereogenic centre, reinstates the dependence of $\Sigma g$ on the electronics of the para-substituent with a slope of $0.11 \pm 0.02$ (Figure 3). In comparison to the sulfoxide, the average $\Sigma g$ value is slightly decreased to $0.76 \pm 0.05$ with the difference between the minimal and maximal $\Sigma g$ values being $17 \%$. Based on a previously published molecular structure of sulfone $3 \mathbf{j}\left(C C D C\right.$ 1048078), $J^{\text {anti }}=46.1 \mathrm{~Hz}$ and $J^{\text {gauche }}=11.8 \mathrm{~Hz}$ were calculated (F-C1-C2: $109.5^{\circ}, \mathrm{C} 1-\mathrm{C} 2-\mathrm{H}: 108.6^{\circ}$ ) affording $\Sigma g=0.70$ in good agreement with the gauche preference verified by the F-C-C-S dihedral angle of $-68.12^{\circ}$. In keeping with the results delineated for the sulfide 
system, the angle-dependent approach afforded a slightly smaller preference for the gauche conformers than an angle-independent treatment.

Finally, the solution phase conformation of $S$-(2-fluoroethyl) thioacetate (4) and 1-fluoro-2thiocyanatoethane (5) were analysed, which were predicted to display almost no asmall -0.15 $\mathrm{kcal} \mathrm{mol}^{-1} \mathrm{f}$ and a more pronounced small gauche $\left(0.730 .4-0.8 \mathrm{kcal} \mathrm{mol}^{-1}\right)$ preference in dichloromethane, respectively. These values were previously calculated using the polarizable continuum model. ${ }^{[4]}$ However, in the same report it was also suggested that explicit solute-solute and solute-solvent effects are likely to shift these conformational equilibria to favour the gauche conformer. Coupling constants of $21.5 \mathrm{~Hz}$ for 4 and values of $J^{\text {anti }}=47.9 \mathrm{~Hz}$ and $J^{\text {gauche }}=8.2 \mathrm{~Hz}$ were determined, indicating a moderate preference for the gauche the absence of a clear preference for either conformer ( $\Sigma$ g:anti $=0.67: 0.33)$ in $\mathrm{CDCl}_{3}$.

Compound 5 displays a similar conformational behaviour with respective values of $\left\langle^{3} J_{\mathrm{HF}}\right\rangle=21.4 \mathrm{~Hz}$, $J^{\text {anti }}=48.5 \mathrm{~Hz}$ and $J^{\text {gauche }}=8.3 \mathrm{~Hz}(\Sigma g: a n t i=0.65: 0.35)$. To improve the comparison with the computational approach, the respective coupling constants were also determined in $\mathrm{CD}_{2} \mathrm{Cl}_{2}\left(<^{3} \mathrm{JF}_{\mathrm{HF}}>(\mathbf{4})\right.$ $=21.7 \mathrm{~Hz}$ and $\left.<^{3} \mathrm{~J}_{\mathrm{HF}}>(\mathbf{5})=22.2 \mathrm{~Hz}\right)$ : this did not result in significant changes for 4 ( $\Sigma g$ :anti $\left.=0.68: 0.32\right)$ or for 5 ( $\Sigma g: a n t i=0.69: 0.31)$. Overall, these data substantiate the initial prediction of almost no or a small gauche preference in these structurally related systems.

\section{Conclusions}

In summary, the effect of subtle electronic perturbations on the conformational equilibria of F-C1-C2$\mathrm{S}(\mathrm{O})_{\mathrm{n}} \mathrm{R}$ systems has been investigated by solution phase NMR-based analysis. Generally, upon introduction of increasingly electron-deficient substituents, the gauche conformers become increasingly populated leading to population differences of up to $17 \%$ between the most electron-donating $\left(R=\mathrm{NH}_{2}\right)$ and electron-withdrawing $\left(\mathrm{R}=\mathrm{NO}_{2}\right)$ substituents investigated. Sequential oxidation of sulfur $(n=1,2)$ has a more pronounced influence on conformational behaviour than the 
para-substituent. The $\Sigma g$ populations of on average $48 \%$ for sulfides $(n=0)$ increase significantly to 85 and $76 \%$ for the sulfoxide $(n=1)$ and sulfone $(n=2)$ systems, respectively - this is in contrast to a recent computational study which suggested that sulfones preferentially adopt gauche arrangement over sulfoxide systems. This study demonstrates that the sulfur-fluorine gauche effect can be further tuned by the simple introduction of a para-substituted aryl sulfide, sulfoxide or sulfone unit into the model systems (i.e. F-C1-C2-S(O) ${ }_{n} \mathrm{Ar}$ ). Efforts to exploit this phenomenon in molecular design are ongoing and will be reported in due course.

\section{Experimental}

Full experimental details are provided in the supporting information.

\section{(2-Fluoroethyl)(phenyl)sulfane (1e)}

To a solution of 2-fluoroethane tosylate $(302 \mathrm{mg}, 1.38 \mathrm{mmol}, 1.0 \mathrm{eq}$.$) in toluene (7 \mathrm{ml})$ were added sequentially thiophenol (170 $\mu \mathrm{l}, 1.66 \mathrm{mmol}, 1.2$ eq.) and DBU $(270 \mu \mathrm{l}, 1.80 \mathrm{mmol}, 1.3$ eq.) and the mixture was stirred at $\mathrm{rt}$ for $6 \mathrm{~h}$ under an atmosphere of argon. The reaction mixture was diluted with EtOAc $(10 \mathrm{ml})$ and was then washed with aq. sat. $\mathrm{NH}_{4} \mathrm{Cl}(10 \mathrm{ml}), 1 \mathrm{M} \mathrm{NaOH}(2 \times 8 \mathrm{ml})$ and brine. The separated organic layer was dried over $\mathrm{Na}_{2} \mathrm{SO}_{4}$ and concentrated under reduced pressure. Separation via column chromatography on silica gel (pentane) afforded the desired product as colourless oil (154 mg, 71\%).

$\boldsymbol{R}_{\mathrm{f}}=0.35$ (pentane); ${ }^{1} \mathrm{H}$ NMR $\left(400 \mathrm{MHz}, \mathrm{CDCl}_{3}\right) \delta=7.42-7.38(2 \mathrm{H}, \mathrm{m}, \mathrm{H}-\mathrm{C} 5), 7.34-7.28(2 \mathrm{H}, \mathrm{m}, \mathrm{H}-\mathrm{C} 4)$, 7.26-7.21 (1H, m, H-C6), $4.54\left(2 \mathrm{H}, \mathrm{dt},{ }^{2} J_{\mathrm{HF}}=47.0,{ }^{3} J_{\mathrm{HH}}=6.8, \mathrm{H}-\mathrm{C} 1\right), 3.21\left(2 \mathrm{H}, \mathrm{dt},{ }^{3} J_{\mathrm{HF}}=17.0,{ }^{3} \mathrm{~J}_{\mathrm{HH}}=6.9\right.$, H-C2) ppm; ${ }^{13} \mathrm{C}$ NMR (101 MHz, CDCl 3 ) $\delta=134.9$ (C3), 130.4 (2C, C5), 129.3 (2C, C4), 127.0 (C6), 81.7 $\left(\mathrm{d},{ }^{1} J_{\mathrm{CF}}=172.5, \mathrm{C} 1\right), 33.8\left(\mathrm{~d},{ }^{2} J_{\mathrm{CF}}=21.6, \mathrm{C} 2\right) \mathrm{ppm} ;{ }^{19} \mathrm{~F} \mathrm{NMR}\left(282 \mathrm{MHz}, \mathrm{CDCl}_{3}\right) \delta=-212.43(1 \mathrm{~F}, \mathrm{tt}$, $\left.{ }^{2} J_{\mathrm{HF}}=47.0,{ }^{3} J_{\mathrm{HF}}=17.0, \mathrm{~F}-\mathrm{C} 1\right) \mathrm{ppm} ;$ IR (ATR) $\tilde{v}=3060 \mathrm{w}, 2963 \mathrm{w}, 2895 \mathrm{w}, 1583 \mathrm{~m}, 1480 \mathrm{~m}, 1439 \mathrm{~m}$, $1404 w, 1385 w, 1288 w, 1231 w, 1197 w, 1088 w, 1059 m, 1024 m, 1006 m, 986 m, 955 m, 898 w, 813 w$, 
737s, $689 \mathrm{~s} \mathrm{~cm}^{-1}$; GC-MS (EI): $t_{\mathrm{R}}=8.63 \mathrm{~min}, \mathrm{~m} / \mathrm{z}: 156.0\left(\mathrm{M}^{+}\right)$. Spectroscopic data are in agreement with previous literature. ${ }^{[13]}$

\section{((2-Fluoroethyl)sulfinyl)benzene (2e)}

A solution of 1 e $\left(76 \mathrm{mg}, 0.49 \mathrm{mmol}, 1.00\right.$ eq.) in $\mathrm{CH}_{2} \mathrm{Cl}_{2}(8 \mathrm{ml})$ was cooled to $0{ }^{\circ} \mathrm{C}$ and $m \mathrm{mPBA}$ ( $\leq 77 \%$, $118 \mathrm{mg}, 0.51 \mathrm{mmol}, 1.05 \mathrm{eq}$.) was added. After stirring for $16 \mathrm{~h}$ under an atmosphere of argon while warming to rt, the mixture was washed with aq. sat. $\mathrm{NaHCO}_{3}(6 \mathrm{ml})$, brine, was dried over $\mathrm{Na}_{2} \mathrm{SO}_{4}$ and concentrated under reduced pressure. Separation by column chromatography on silica gel (CyH/EtOAc 1:1) afforded the desired product as colourless oil (49 mg, 58\%).

$\boldsymbol{R}_{\mathrm{f}}=0.25(\mathrm{CyH} / \mathrm{EtOAC} 1: 1) ;{ }^{1} \mathrm{H}$ NMR $\left(400 \mathrm{MHz}, \mathrm{CDCl}_{3}\right) \delta=7.67-7.63(2 \mathrm{H}, \mathrm{m}, \mathrm{H}-\mathrm{C} 5), 7.57-7.51(3 \mathrm{H}, \mathrm{m}, \mathrm{H}-$ C4/C6), $4.92\left(1 \mathrm{H}, \mathrm{dddd},{ }^{2} J_{\mathrm{HF}}=46.9,{ }^{2} J_{\mathrm{HH}}=10.5,{ }^{3} J_{\mathrm{HH}}=8.5,3.8, \mathrm{H}-\mathrm{C} 1\right), 4.72\left(1 \mathrm{H}, \mathrm{dddd},{ }^{2} J_{\mathrm{HF}}=46.3,{ }^{2} J_{\mathrm{HH}}=\right.$ $\left.10.5,{ }^{3} J_{H H}=4.8,4.6, \mathrm{H}-\mathrm{C} 1\right), 3.11\left(1 \mathrm{H}, \mathrm{dddd},{ }^{3} J_{\mathrm{HF}}=19.5,{ }^{2} J_{\mathrm{HH}}=13.8,{ }^{3} J_{H H}=8.4,4.6, \mathrm{H}-\mathrm{C} 2\right), 3.07(1 \mathrm{H}, \mathrm{dddd}$, $\left.{ }^{3} J_{\mathrm{HF}}=30.1,{ }^{2} J_{\mathrm{HH}}=13.9,{ }^{3} J_{\mathrm{HH}}=4.8,3.8, \mathrm{H}-\mathrm{C} 2\right) \mathrm{ppm} ;{ }^{13} \mathrm{C} \mathrm{NMR}\left(101 \mathrm{MHz}, \mathrm{CDCl}_{3}\right) \delta=143.5$ (C3), 131.5 (C6), $129.6(2 \mathrm{C}, \mathrm{C} 4), 124.0(2 \mathrm{C}, \mathrm{C} 5), 76.8\left(\mathrm{~d},{ }^{1} J_{\mathrm{CF}}=170.4, \mathrm{C} 1\right), 58.2\left(\mathrm{~d},{ }^{2} \mathrm{~J}_{\mathrm{CF}}=19.6, \mathrm{C} 2\right) \mathrm{ppm} ;{ }^{19} \mathrm{~F} \mathrm{NMR}$ $\left(282 \mathrm{MHz}, \mathrm{CDCl}_{3}\right) \delta=-220.99\left(1 \mathrm{~F}, \mathrm{tdd},{ }^{2} J_{\mathrm{HF}}=46.6,{ }^{3} J_{\mathrm{HF}}=30.1,19.5, \mathrm{~F}-\mathrm{C} 1\right) \mathrm{ppm} ; \mathrm{IR}$ (ATR) $\tilde{v}=3055 \mathrm{w}$, 2967w, 2901w, 1474m, 1443m, 1389m, 1088m, 1038s, 991s, 957m, 829w, 745s, 691s, 633m cm $\mathrm{cm}^{-1}$ HRMS (ESI): $m / z: 195.0253\left([\mathrm{M}+\mathrm{Na}]^{+}\right.$, calcd. for $\mathrm{C}_{8} \mathrm{H}_{9} \mathrm{FOSNa}^{+}:$195.0250).

\section{((2-Fluoroethyl)sulfonyl)benzene (3e)}

A solution of $1 \mathrm{e}\left(20 \mathrm{mg}, 0.13 \mathrm{mmol}, 1.0\right.$ eq.) in $\mathrm{CH}_{2} \mathrm{Cl}_{2}(2.5 \mathrm{ml})$ was cooled to $0{ }^{\circ} \mathrm{C}$ and $m \mathrm{mPBA}(\leq 77 \%$, $74 \mathrm{mg}, 0.32 \mathrm{mmol}, 2.5$ eq.) was added. After stirring for $7 \mathrm{~h}$ under an atmosphere of argon while warming to rt, the mixture was washed with aq. $\mathrm{Na}_{2} \mathrm{SO}_{3}(5 \%, 6 \mathrm{ml})$, aq. sat. $\mathrm{NaHCO}_{3}(2 \times 5 \mathrm{ml})$ and brine. The separated organic layer was dried over $\mathrm{Na}_{2} \mathrm{SO}_{4}$ and concentrated under reduced pressure. 
Separation by column chromatography on silica gel (CyH/EtOAc 3:1) afforded the desired product as colourless oil ( $20 \mathrm{mg}, 82 \%)$.

$\boldsymbol{R}_{\mathrm{f}}=0.25\left(\mathrm{CyH} /\right.$ EtOAC 1:1); ${ }^{1} \mathrm{H}$ NMR $\left(400 \mathrm{MHz}, \mathrm{CDCl}_{3}\right) \delta=7.96-7.92(2 \mathrm{H}, \mathrm{m}, \mathrm{H}-\mathrm{C} 5), 7.70-7.65(1 \mathrm{H}, \mathrm{m}, \mathrm{H}-$ C6), 7.61-7.55 (2H, m, H-C4), $4.80\left(2 \mathrm{H}, \mathrm{dt},{ }^{2} \mathrm{~J}_{\mathrm{HF}}=46.5,{ }^{3} \mathrm{~J}_{\mathrm{HH}}=5.6, \mathrm{H}-\mathrm{C} 1\right), 3.52\left(2 \mathrm{H}, \mathrm{dt},{ }^{3} J_{\mathrm{HF}}=22.0,{ }^{3} J_{\mathrm{HH}}=\right.$ 5.6, H-C2) ppm; ${ }^{13} \mathrm{C}$ NMR (101 MHz, CDCl $) \delta=139.5$ (C3), 134.2 (C6), 129.5 (2C, C4), 128.2 (2C, C5), $77.2\left(\mathrm{~d},{ }^{1} J_{\mathrm{CF}}=173.1, \mathrm{C} 1\right), 56.9\left(\mathrm{~d},{ }^{2} J_{\mathrm{CF}}=21.5, \mathrm{C} 2\right) \mathrm{ppm} ;{ }^{19} \mathrm{~F}$ NMR $\left(282 \mathrm{MHz}, \mathrm{CDCl}_{3}\right) \delta=-221.42(1 \mathrm{~F}, \mathrm{tt}$, $\left.{ }^{2} J_{\mathrm{HF}}=46.5,{ }^{3} J_{\mathrm{HF}}=22.0, \mathrm{~F}-\mathrm{C} 1\right) \mathrm{ppm} ; \mathrm{IR}$ (ATR) $\tilde{v}=2932 \mathrm{w}, 1447 \mathrm{~m}, 1389 \mathrm{w}, 1319 \mathrm{~m}, 1292 \mathrm{~m}, 1246 \mathrm{w}$, 1184w, 1142s, 1088m, 1065m, 999m, 961w, 768m, 729s, 687s, $594 \mathrm{~m} \mathrm{~cm}^{-1}$; HRMS (ESI): $\mathrm{m} / \mathrm{z}$ : 211.0209 ([M+Na $]^{+}$, calcd. for $\mathrm{C}_{8} \mathrm{H}_{9} \mathrm{FO}_{2} \mathrm{SNa}^{+}:$211.0199)

\section{$S$-(2-Fluoroethly) ethanethioate $(4)^{[7]}$}

2-Fluoroethane tosylate $(0.4 \mathrm{~g}, 1.8 \mathrm{mmol}, 1.0$ eq.) and potassium thioacetate $(0.25 \mathrm{~g}, 2.2 \mathrm{mmol}, 1.2$ eq.) were suspended in acetone $(6 \mathrm{~mL})$ and heated to $70{ }^{\circ} \mathrm{C}$ for $4 \mathrm{~h}$. The reaction mixture was filtered and the residual was washed with copious amounts of acetone. The brown filtrate was concentrated under reduced pressure. Subsequently, the residual was partitioned between $\mathrm{H}_{2} \mathrm{O}$ and $\mathrm{Et}_{2} \mathrm{O}$ and the organic layer was dried over $\mathrm{MgSO}_{4}$ and concentrated under reduced pressure. Fractional distillation (40 mbar, $50^{\circ} \mathrm{C}$ ) afforded the title product as a colourless liquid $(0.1 \mathrm{~g}, 44 \%)$. Spectroscopic data in agreement with previously published ones. ${ }^{[6]}$

${ }^{1} \mathrm{H}$ NMR $\left(400 \mathrm{MHz}, \mathrm{CDCl}_{3}\right) \delta=4.50\left(2 \mathrm{H}, \mathrm{dt},{ }^{2} J_{\mathrm{HF}}=46.9,{ }^{3} J_{\mathrm{HH}}=6.2, \mathrm{H}-\mathrm{C} 1\right), 3.19\left(2 \mathrm{H}, \mathrm{dt},{ }^{3} J_{\mathrm{HF}}=21.5,{ }^{3} J_{\mathrm{HH}}=\right.$ 6.2, H-C2), $2.36(3 \mathrm{H}, \mathrm{s}, \mathrm{H}-\mathrm{C} 4) \mathrm{ppm} ;{ }^{13} \mathrm{C}$ NMR $\left(101 \mathrm{MHz}, \mathrm{CDCl}_{3}\right) \delta=195.0$ (C3), 81.9 (d, $\left.{ }^{1} J_{\mathrm{CF}}=170.7, \mathrm{C} 1\right)$, $30.7(\mathrm{C} 4), 29.3\left(\mathrm{~d},{ }^{2} J_{\mathrm{CF}}=22.1, \mathrm{C} 2\right) \mathrm{ppm} ;{ }^{19} \mathrm{~F}$ NMR $\left(282 \mathrm{MHz}, \mathrm{CDCl}_{3}\right) \delta=-213.95\left(1 \mathrm{~F}, \mathrm{tt},{ }^{2} J_{\mathrm{HF}}=46.9,{ }^{3} J_{\mathrm{HF}}=\right.$ 21.6, F-C1) ppm; IR (ATR) $\tilde{v}=2963 \mathrm{w}, 1694 \mathrm{~s}, 1686 \mathrm{~s}, 1420 \mathrm{w}, 1385 \mathrm{w}, 1354 \mathrm{~m}, 1134 \mathrm{~m}, 1115 \mathrm{~m}, 1065 \mathrm{~m}$, $1015 \mathrm{~m}, 995 \mathrm{~m}, 967 \mathrm{~m}, 810 \mathrm{w}, 683 \mathrm{w}, 621 \mathrm{sm}^{-1}$; GC-MS (EI): $t_{\mathrm{R}}=4.35 \mathrm{~min}, \mathrm{~m} / \mathrm{z} 122.0\left(\mathrm{M}^{+}\right)$. 
A mixture of 2-fluoroethane tosylate $(218 \mathrm{mg}, 1.0 \mathrm{mmol}, 1.0 \mathrm{eq}$ ) and $\mathrm{NaSCN}$ (122 mg, $1.5 \mathrm{mmol}$, 1.5 eq.) in $\mathrm{H}_{2} \mathrm{O}(0.2 \mathrm{ml})$ was heated to $100^{\circ} \mathrm{C}$ for $5 \mathrm{~h}$. After reaching $\mathrm{rt}$, the mixture was diluted with $\mathrm{H}_{2} \mathrm{O}(5 \mathrm{ml})$ and extracted with $\mathrm{Et}_{2} \mathrm{O}(3 \times 5 \mathrm{ml})$. The combined organic layers were dried over $\mathrm{Na}_{2} \mathrm{SO}_{4}$ and most of the $\mathrm{Et}_{2} \mathrm{O}$ was removed under reduced pressure. The obtained brown oil was purified via fractional distillation $\left(12-35 \mathrm{mbar}, 33^{\circ} \mathrm{C}\right)$ to give the desired product as a colourless liquid $(40 \mathrm{mg}$, $38 \%)$.

${ }^{1} \mathrm{H} \mathrm{NMR}\left(400 \mathrm{MHz}, \mathrm{CDCl}_{3}\right) \delta=4.74\left(2 \mathrm{H}, \mathrm{dt},{ }^{2} \mathrm{~J}_{\mathrm{HF}}=46.4,{ }^{3} J_{\mathrm{HH}}=5.6, \mathrm{H}-\mathrm{C} 1\right), 3.24\left(2 \mathrm{H}, \mathrm{dt},{ }^{3} \mathrm{JFF}_{\mathrm{HF}}=21.4,{ }^{3} \mathrm{~J}_{\mathrm{HH}}=\right.$ 5.6, H-C2) ppm; ${ }^{13} \mathrm{C} \mathrm{NMR}\left(101 \mathrm{MHz}, \mathrm{CDCl}_{3}\right) \delta=111.2(\mathrm{C} 3), 80.7\left(\mathrm{~d},{ }^{1} J_{\mathrm{CF}}=174.7, \mathrm{C} 1\right), 33.8\left(\mathrm{~d},{ }^{2} J_{\mathrm{CF}}=22.3\right.$, C2) ppm; ${ }^{19} \mathrm{~F}$ NMR $\left(282 \mathrm{MHz}, \mathrm{CDCl}_{3}\right) \delta=-217.07\left(1 \mathrm{~F}, \mathrm{tt},{ }^{2} J_{\mathrm{HF}}=46.4,{ }^{3} \mathrm{~J}_{\mathrm{HF}}=21.4, \mathrm{~F}-\mathrm{C} 1\right) \mathrm{ppm}$; IR (ATR) $\tilde{v}=$ 2963w, 2901w, 2156m, 1404m, 1296m, 1196w, 1065m, 1015s, 953m, 822m, 633m cm ${ }^{-1}$; GC-MS (EI): $t_{\mathrm{R}}=4.10 \mathrm{~min}, \mathrm{~m} / \mathrm{z} 105.1\left(\mathrm{M}^{+}\right)$. Spectroscopic data are in agreement with previous literature. ${ }^{[14]}$

\section{Acknowledgements}

We acknowledge generous financial support from the Swiss National Science Foundation (N. S., P300P2_161070), the DFG (SFB 858 and Excellence Cluster EXC 1003 "Cells in Motion - Cluster of Excellence"), the European Research Council (ERC-2013-StG Starter Grant. Project number 336376ChMiFluorS) and the WWU Münster.

\section{References}

1. (a) S. Wolfe, Acc. Chem. Res. 5 (1972) 102-111; (b) D. O'Hagan, Chem. Soc. Rev. 37 (2008) 308-319; (c) L. Hunter, Beilstein J. Org. Chem. 38 (2010) doi:10.3762/bjoc.6.38; (d) L. E. Zimmer, C. Sparr , R. Gilmour, Angew. Chem. Int. Ed. 50 (2011) 11860-11871. 
2. For selected examples see: (a) K. S. Buckton, R. G. Azrak, J. Chem. Phys. 52 (1970) 5652-5655; (b) K. Hagen, K. Hedberg, J. Am. Chem. Soc. 95 (1973) 8263-8266; (c) J. Huang, K. Hedberg, J. Am. Chem. Soc. 111 (1989) 6909-6913; (d) D. A. Dixon, B. E. Smart, J. Phys. Chem. 95 (1991) 1609-1612; (e) D. O'Hagan, H. S. Rzepa, Chem. Commun. (1997) 645-652; (f) D. O'Hagan, C. Bilton, J. A. K. Howard, L. Knight, D. J. Tozer, J. Chem. Soc., Perkin Trans. 2 (2000), 605-607; (g) C. R. S. Briggs, M. J. Allen, D. O’Hagan, D. J. Tozer, A. M. Z. Slawin, A. E. Goeta, J. A. K. Howard, Org. Biomol. Chem. 2 (2004) 732-740; (h) C. R. S. Briggs, D. O'Hagan, H. S. Rzepa, A. M. Z. Slawin, J. Fluorine Chem. 125 (2004) 19-25; (i) M. Morgenthaler, E. Schweizer, A. Hoffman-Röder, F. Benini, R. E. Martin, G. Gaeschke, B. Wagner, H. Fischer S. Bendels, D. Himmerli, J. Schneider, F. Diederich, M. Kansy, K. Müller, ChemMedChem 2 (2007) 11001115; (j) N. E. J. Gooseman, D. O’Hagan, M. J. G. Peach, A. M. Z. Slawin, D. J. Tozer, R. J. Young, Angew. Chem. Int. Ed. 46 (2007) 5904-5908; (k) G. Deniau, A. M. Z. Slawin, T. Lebl, F. Chorki, J. P. Issberner, T. van Mourik, J. M. Heygate, J. J. Lambert, K. T. Sillar, D. O’Hagan, ChemBioChem 8 (2007) 2265-2274; (I) C. Sparr, W. B. Schweizer, H. M. Senn, R. Gilmour, Angew. Chem. Int. Ed. 48 (2009) 3065-3068.; (m) C. Bucher, C. Sparr, W. B. Schweizer, R. Gilmour, Chem. Eur. J. 15 (2009) 7637-7647; (n) C. Sparr, R. Gilmour, Angew. Chem. Int. Ed. 49 (2010) 6520-6523; (o) C. Sparr, E.-M. Tanzer, J. Bachmann, R. Gilmour, Synthesis 8 (2010) 1394-1397; (p) S. Paul, W. B. Schweizer, M.-O. Ebert, R. Gilmour, Organometallics 29 (2010) 4424-4427; (q) C. Sparr, E. Salamanova, W. B. Schweizer, H. M. Senn, R. Gilmour, Chem. Eur. J. 17 (2011) 8850-8857; (r) E.-M. Tanzer, L. E. Zimmer, W. B. Schweizer, R. Gilmour, Chem. Eur. J. 18 (2012) 11334-11342; (s) E.-M. Tanzer, W. B. Schweizer, M.-O. Ebert, R. Gilmour, Chem. Eur. J. 18 (2012) 2006-2013; (t) S. Paul, W. B. Schweizer, G. Rugg, H. M. Senn, R. Gilmour, Tetrahedron 69 (2013) 5647-5659; (u) Y. P. Rey, R. Gilmour, Beilstein J. Org. Chem. 9 (2013) 2812-2820; (v) Y. P. Rey, L. E. Zimmer, C. Sparr, E.-M. Tanzer, W. B. Schweizer, H. M. Senn, S. Lakhdar, R. Gilmour, Eur. J. Org. Chem. (2014) 1202-1211; (w) I. G. Molnár, E.-M. Tanzer, C. Daniliuc, R. Gilmour, Chem. Eur. J. 20 (2014) 794-800.

3. C. Thiehoff, M. C. Holland, C. Daniliuc, K. N. Houk, R. Gilmour, Chem. Sci. 6 (2015) 3565-3571. 
4. J. Aleksić, M. Stojanović, M. Baranac-Stojanović, J. Org. Chem. 80 (2015) 10197-10207.

5. M. C. Holland, R. Gilmour, Angew. Chem. Int. Ed. 54 (2015) 3862-3871.

6. (a) J. T. G. Hamilton, M. R. Amin, D. B. Harper, D. O'Hagan, Chem. Commun. (1997) 797-798;

(b) C. D. Murphy, C. Schaffrath, D. O'Hagan, Chemosphere 52 (2003) 455-461.

7. W. C. Howell, J. E. Millington, F. L. M. Pattison, J. Am. Chem. Soc. 78 (1956) 3843-3846.

8. S. Hamman, C. Béguin, C. Charlon, C. Luu-Duc, Org. Magn. Reson. 21 (1983) 361-366.

9. C. Altona, J. H. Ippel, A. J. A. Westra Hoekzeman, C. Erkelens, M. Groesbeek, L. A. Donders Org. Mag. Reson. 27 (1989) 564-576.

10. C. Hansch, A. Leo, D. Hoekman, QSAR: Volume 2: Hydrophobic, Electronic, and Steric Constants, American Chemical Society (1995).

11. CCDC number 1438639 contains the supplementary crystallographic data for sulfide $\mathbf{1 h}$. These data can be obtained free of charge from The Cambridge Crystallographic Data Centre via www.ccdc.cam.ac.uk/data_request/cif.

12. C. Thibaudeau, J. Plavec, J. Chattopadhayaya, J. Org. Chem. 63 (1998) 4967-4984.

13. T. Fuchigami, K. Yamamoto, A. Konno, Tetrahedron 47 (1991) 635-634.

14. W. Ellouze, M. M. Chaabouni, A. Baklouti, J. Fluorine Chem. 37 (1987) 61-66. 